\section{Stimulation of Lateral Branching of Red Firespike Using Dikegulac Sodium, Benzyladenine, and Pinching}

\author{
Amir Rezazadeh ${ }^{1}$, Richard L. Harkess, and Guihong Bi
}

ADDITIONAL INDEX WORDs. chemical pinching, Odontonema strictum, plant growth regulator

SUMMARY. Red firespike (Odontonema strictum) is an ornamental shrub with potential for use as a flowering potted plant due to its dark green foliage and attractive red flower spikes. To stimulate branching and improve quality of red firespike, foliar spray applications of dikegulac sodium (DS) and benzyladenine (BA) and hand pinching were evaluated across two seasons (Spring and Summer 2014). There were three pinching treatments: one, two, or three pinches. Plant growth regulators (PGRs) were applied at 400, 800, 1600, or $2400 \mathrm{ppm}$ DS or 600, 1000,1250 , or $1750 \mathrm{ppm} \mathrm{BA}$. Both studies included an untreated control. Red firespike treated with all concentrations of BA and 1600 and $2400 \mathrm{ppm}$ DS had increased branching compared with the control, except 1000 ppm BA in Expt. 1. Pinching did not affect the number of branches. Dikegulac sodium at 1600 and $2400 \mathrm{ppm}$ and all concentrations of BA resulted in shorter plants than the control. Phytotoxicity was observed in plants treated with 1600 or 2400 ppm DS. In both experiments, DS at 1600 and $2400 \mathrm{ppm}$ had the least plant dry weight compared with the control. Treatment with $B A$ at $1750 \mathrm{ppm}$ resulted in greatest leaf area compared with control. Dikegulac sodium at $800 \mathrm{ppm}$ increased the number of flowers compared with control. Pinching and BA did not affect number of inflorescences. All concentrations of BA and DS delayed flowering, except 1000 ppm BA. Plants treated with 800, 1600, and 2400 ppm DS had shorter inflorescences compared with control plants. Benzyladenine decreased the length of the inflorescence at high concentrations, 1250 and $1750 \mathrm{ppm}$. Pinching treatments did not affect inflorescence length.

$\mathrm{R}$ ed firespike is a vigorous ornamental shrub growing to $\approx$ $1.8 \mathrm{~m}$ in height (Daniel and McDade, 1995). Red firespike has an upright growth habit and is commonly cultivated as an ornamental plant in the garden due to its attractive tubular red flowers. The plant has the potential to become a popular flowering potted plant because of its attractive red flower spikes and dark green foliage. Since the plant tends to grow upright, enhanced branching has the potential to improve plant architecture, increase number of inflorescences, control plant height, produce uniform plants, and increase available propagules on stock plants (Latimer and

Department of Plant and Soil Science, Mississippi State University, 117 Dorman Hall, Box 9555, Mississippi State, MS 39762

Contribution of the Mississippi Agricultural and Forestry Experiment Station Journal article no. J-12648.

Mention of a trademark, proprietary product, or vendor does not constitute a guarantee or warranty of the product by Mississippi State University and does not imply its approval to the exclusion of other products or vendors that also may be suitable.

${ }^{1}$ Corresponding author. E-mail: ar1372@msstate.edu.
Freeborn, 2010). Controlling the plant's architecture will meet marketing requirements and provide more uniform and well-shaped, symmetrical plants.

To achieve better uniformity, growers often use cultural practices including hand pinching and PGRs to release apical dominance. This allows dormant, lateral buds to grow resulting in well-branched plants (Grossman et al., 2013). Pinching promotes lateral branch development and more synchronous flowering (Larson, 1985). Pinching controls plant height, enhances plant width, and increases the number of branches (Beniwal et al., 2003; Rakesh et al., 2003). The number of branches per pot in purple firespike increased significantly as number of cuttings and pinches increased (Rezazadeh and Harkess, 2015). However, hand pinching is labor intensive and does not always result in optimal branching (Hester et al., 2013), thereby chemical pinching has been used to enhance lateral branching. Application of PGRs is generally less labor intensive than hand pinching; however, PGRs may cause phytotoxicity (Meijón et al., 2009).

Plant growth regulators with different modes of action have been developed to suppress apical dominance and enhance branching. Dikegulac sodium is translocated in the phloem to the apical meristem, inhibiting DNA synthesis resulting in a chemical pinching effect. Benzyladenine, a synthetic cytokinin, is commonly used to promote branching in ornamental plants (Latimer and Freeborn, 2008). A previous study showed a foliar spray of $\mathrm{BA}$ at 300 or $600 \mathrm{ppm}$ doubled the number of branches in 'White Swan' and 'Double Decker' purple coneflower (Echinacea purpurea) 2 weeks after transplanting (Latimer and Freeborn, 2008). Multiple BA applications increased branching without any impact on growth index (GI) in nandina [Nandina domestica (Keever and Morrison, 2003)]. Two applications of 80 or $160 \mathrm{ppm} \mathrm{BA}$, with the second application 3 weeks after the first, increased branching and flowering of petunia [Petunia (Carey et al., 2008)]. Grossman et al. (2012) reported an increase in branching in four of five herbaceous perennials treated with BA before transplanting.

Dikegulac sodium and BA have been used to effectively enhance branching in bigleaf hydrangea [Hydrangea macrophylla (Hester et al., 2013)]. Foliar sprays of 400 or 800 ppm DS increased branching of 'Gallo Yellow' blanket flower [Gaillardia aristata (Latimer and Freeborn, 2010)]. Dikegulac sodium at 800 or $1600 \mathrm{ppm}$ increased

\begin{tabular}{llll}
\hline $\begin{array}{l}\text { Units } \\
\text { To convert U.S. to SI, } \\
\text { multiply by }\end{array}$ & U.S. unit & SI unit & $\begin{array}{l}\text { To convert SI to U.S., } \\
\text { multiply by }\end{array}$ \\
\hline 0.3048 & $\mathrm{ft}$ & $\mathrm{m}$ & 3.2808 \\
0.4075 & $\mathrm{gal} / 100 \mathrm{ft}^{2}$ & $\mathrm{~L} \cdot \mathrm{m}^{-2}$ & 2.4542 \\
2.54 & inch(es) & $\mathrm{cm}$ & 0.3937 \\
6.4516 & $\mathrm{~cm}^{2}$ & 0.1550 \\
16.3871 & inch $^{3}$ & $\mathrm{~cm}^{3}$ & 0.0610 \\
28.3495 & $\mathrm{Oz}$ & $\mathrm{g}$ & 0.0353 \\
1 & $\mathrm{ppm}$ & $\mathrm{mg} \cdot \mathrm{L}^{-1}$ & 1 \\
$\left({ }^{\circ} \mathrm{F}-32\right) \div 1.8$ & ${ }^{\circ} \mathrm{F}$ & ${ }^{\circ} \mathrm{C}$ & $\left({ }^{\circ} \mathrm{C} \times 1.8\right)+32$
\end{tabular}


branch number of pruned and unpruned 'Limelight' panicle hydrangea [Hydrangea paniculata (Cochran et al., 2013)]. The foliar application of DS between 4000 and 6000 ppm suppressed dominant shoots and enhanced uniform regrowth without causing marked chlorosis or shoot distortion in orange jessamine [Murraya paniculata (Kawabata and Criley, 1996)].

Plant response to PGRs varies under different environmental and cultural conditions; therefore, it is recommended to test the efficacy of PGRs on individual plant species (Currey and Erwin, 2012). The objective of this study was to evaluate branching, vegetative growth, and flowering of potted red firespike following pinching or PGR applications of DS or BA.

\section{Materials and methods}

This experiment was conducted at Mississippi State University during Spring and repeated in Summer 2014. In both experiments, red firespike cuttings with about three to five nodes were rooted from vegetative stock plants. Cuttings were rooted under intermittent mist at $78{ }^{\circ} \mathrm{F}$ for 4 weeks in a glass-glazed greenhouse. After rooting, the cuttings were transplanted to 6-inch-diameter pots containing commercial potting substrate (Sunshine Mix 1; Sun Gro Horticulture, Bellevue, WA) and grown under natural daylength until flowering, $\approx 20$ weeks. Greenhouse air temperature set points were 77 and $71{ }^{\circ} \mathrm{F}$ (day/night). Plants were fertigated using $200 \mathrm{ppm}$ nitrogen from $20 \mathrm{~N}-$ 4.4P-16.6K liquid fertilizer (Peters Peat-Lite 20-10-20; Scotts, Marysville, $\mathrm{OH})$. Pinching treatments included a no-pinch control, one pinch, two pinches, or three pinches. The first pinch was applied after $14 \mathrm{~d}$ growth when plants averaged $6 \mathrm{~cm}$ tall and had an established root system. Plants were soft-pinched by removing the terminal growing point including one or two youngest leaf pairs $(\approx 1$ inch $)$ for best branching results. Two weeks later, the second pinch left four to five nodes per shoot to produce side shoots and shape the plant for a more symmetrical form. The third pinch was made 2 weeks later similar to the second pinch. For each pinching treatment, all terminal shoots including those of new side shoots were pinched. Hand sprayers were used to apply PGRs as a foliar spray at $0.5 \mathrm{gal} / 100 \mathrm{ft}^{2}$. Two PGRs were applied as a foliar spray to red firespike: 400, 800, 1600, or 2400 ppm DS (Augeo; OHP, Mainland, PA) and $600,1000,1250$, or 1750 ppm BA (Configure; Fine Americas, Walnut Creek, CA). A nontreated control was also included.

At the end of each experiment, plant height (from the substrate surface to the tallest point on the plant), width (the average of the width measured at the widest point of the plant and perpendicular to this point), growth index [GI $=\pi$ (average width $/ 2)^{2}$.height , total leaf area (LI-3100 area meter; LI-COR, Lincoln, NB), leaf dry weight (determined after drying leaves at $65^{\circ} \mathrm{C}$ for $3 \mathrm{~d}$ ), number of branches greater than $5 \mathrm{~cm}$, number of inflorescences, length of inflorescences from the base of the peduncle to the terminus, and days to first visible flower bud were recorded. Days to flowering were calculated from rooting to the date when the first immature inflorescence was observed (i.e., visible bud). Eight single plant replications were used in a randomized complete design. Data were analyzed using the general linear model (GLM) procedure of SAS (version 9.3; SAS Institute, Cary, NC) to determine the effect of PGRs and pinching on growth and flowering of plants. Means were separated using the least significant difference test at $P \leq 0.05$.

\section{Results and discussion}

In both experiments, all concentrations of BA application resulted in a greater number of branches compared with control plants, except for BA at 1000 ppm in Expt. 1 (Fig. 1). Dikegulac sodium at 1600 and 2400 ppm had similar effect on number of branches as BA; however, there were no differences in number of branches at 400 and 800 ppm DS and control. None of the pinching treatments increased the number of branches relative to the control (Fig. 1), whereas in a previous study on purple firespike, the number of branches per pot increased as number of pinches increased (Rezazadeh and Harkess,
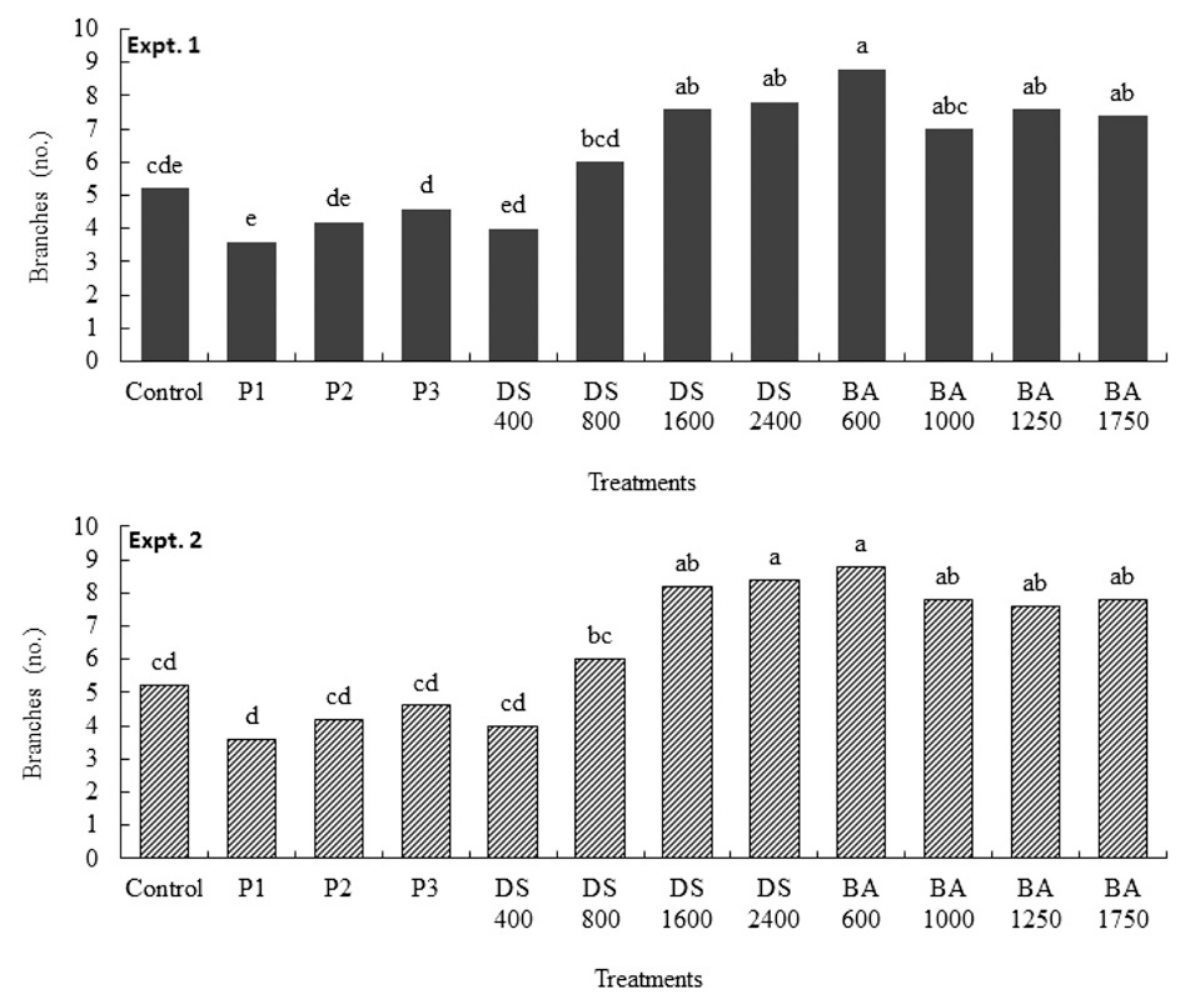

Fig. 1. Number of branches in red firespike 14 weeks after rooting as affected by one, two, or three pinches (P1, P2, or P3); 400, 800, 1600, or $2400 \mathrm{ppm}\left(\mathrm{mg} \cdot \mathrm{L}^{-1}\right)$ dikegulac sodium (DS); or $600,1000,1250$, or $1750 \mathrm{ppm}$ benzyladenine (BA) application. The experiment was repeated in two experiments, Spring and Summer 2014 (Expts. 1 and 2) and each time had eight replications. Columns followed by the same letter are not significantly different. Means were separated using least significant difference test at $P \leq 0.05$. 
2015). These results are consistent with the results of Latimer and Freeborn (2010), who reported foliar application of $600 \mathrm{ppm} \mathrm{BA}$ increased branch number in blanket flower and of Carey et al. (2008), who reported two applications of BA at 80 or 160 ppm on petunia increased branching. Increases in branch number following BA application of two herbaceous ornamental plant species has also been reported by Grossman et al. (2012).

Plants were shorter after treatment with all concentrations of BA compared with control plants (Table 1). Application of DS at $400 \mathrm{ppm}$ resulted in plants similar in height to the control, whereas, DS at 1600 and $2400 \mathrm{ppm}$ resulted in shorter plants than the control. Height reduction following PGR application resulted from breaking of apical dominance and stimulation of axillary bud growth resulting in fuller, more compact plants (Grossman et al., 2012). There were no differences in plant height between pinching treatments and control.

Foliar application of DS at 1600 and $2400 \mathrm{ppm}$ as well as the threepinch treatment resulted in a decrease in plant width compared with the control (Table 1). This may be due to a reduction in leaf size and plant canopy. In both experiments, phytotoxicity was observed for all plants treated with 1600 or 2400 ppm DS as yellow foliage or narrow branches (data not shown). Phytotoxicity following 1600 ppm DS treatment has also been reported in 'Autumn Joy' sedum [Sedum spectabile (Grossman et al., 2013)], in 'Scarlet Flame' zinnia (Zinnia elegans) at $750 \mathrm{ppm}$ (Arzee et al., 1977), and in blanket flower at 800 to 3200 ppm (Latimer and Freeborn, 2010).

Compared with the control plants, overall plant size, as represented by GI, was reduced using DS at concentrations $1600 \mathrm{ppm}$ or higher (Table $\mathrm{l}$ ). Plant height and width were similarly restricted at $1600 \mathrm{ppm}$ or higher DS. Benzyladenine at concentrations greater than 1000 ppm, except in Expt. 1 at $1750 \mathrm{ppm}$, resulted in lower GIs than the control. The reduction in GI with BA was primarily a result of restricted plant height but not plant width. Only the three-pinch treatment had GIs less than the control plants with the reduced GI resulting from the restriction of plant width.
Plants treated with 400 ppm DS, pinched once or twice, and control plants had the greatest GIs, although they were not different from the control. An increase in DS concentration or pinch number resulted in a reduction in GI (Table 1 ). This result was in agreement with Grossman et al. (2013), who reported two applications of DS at $1600 \mathrm{ppm}$ reduced plant growth in all of the crops studied. Growth index also decreased as BA concentration increased up to the 1250 ppm (Table 1).

Increasing $\mathrm{BA}$ concentration resulted in increases in leaf area. Plants treated with $1750 \mathrm{ppm}$ BA had the greatest leaf area compared with control plants. However, greatest reduction in leaf area occurred at $2400 \mathrm{ppm}$ DS in Expt. 1. Only the highest concentration of DS resulted in a decrease in leaf area relative to the control. Pinching treatments had no effect on leaf area compared with the control. Increasing leaf area in plants treated with BA may be due to a promotion effect of BA on cell division (Werner et al., 2001) in leaves resulting in larger leaves as observed in this study. Plants treated with BA had greater plant dry weight than those treated with high concentrations of DS. Plants treated with $2400 \mathrm{ppm}$ DS had the lowest plant dry weight compared with control plants. Reduction in leaf area of plants treated with 2400 ppm DS likely contributed to the decreased dry weight observed at the same DS concentration. An increase in shoot dry weight following BA application has been reported previously in 'Autumn Joy' sedum (Grossman et al., 2013).

Inflorescence number was greatest with 800 ppm DS (five) compared with control (three). The highest concentrations of DS decreased inflorescence numbers. Similar results were found in unpruned panicle hydrangea (Cochran et al., 2013), where the plants treated with 1600 ppm DS had fewer branches and flowers compared with lower concentrations of DS. However, following application of $1600 \mathrm{ppm}$ DS in bougainvillea (Bougainvillea) flower numbers increased (Norcini et al., 1993, 1994). There were no differences in the number of inflorescences between pinching treatments or the control.

Inflorescence length was unaffected by pinching. Benzyladenine at 1250 ppm in Expt. 1 and at 600,
1250, and 1750 ppm in Expt. 2 reduced inflorescence length compared with control. Plants treated with 800,1600 , and 2400 ppm DS had shorter inflorescences than the control plants (Table 1). Cochran et al. (2013) reported DS at 800 and 1600 ppm reduced inflorescence length of panicle hydrangea. Treatment with $1600 \mathrm{ppm}$ DS to garden phlox (Phlox paniculata) plants resulted in shorter flower stalk height compared with the control (Grossman et al., 2013). The reduction in inflorescence length may be useful in height control of red firespike if it causes no reduction in floret number or floret size.

Days to first flower increased in red firespike as concentration of DS and $\mathrm{BA}$ and number of pinches increased. Plants treated with the lowest concentrations of BA and the single pinch treatment flowered as early as the control. Control plants flowered $108 \mathrm{~d}$ after starting the experiment, whereas plants treated with high concentrations of DS flowered $\approx 27$ to $30 \mathrm{~d}$ later than control plants. A delay in flowering of up to $19 \mathrm{~d}$ has been reported in 'Moonbeam' thread-leaved tickseed (Coreopsis verticillata) treated with 1000 to $2000 \mathrm{ppm} \mathrm{BA} \mathrm{(Farris}$ et al., 2009). Previous research demonstrated flowering was delayed up to $28 \mathrm{~d}$ in blanket flower treated with $800 \mathrm{ppm}$ DS whereas plants treated with $1600 \mathrm{ppm}$ DS did not flower during the experiment (Grossman et al., 2013). Two and three pinches delayed flowering up to $25 \mathrm{~d}$. Flowering is an important factor in production of ornamental plants, so a possible delay of flowering should be considered at the time of applying PGRs.

In conclusion, hand pinching is not a practical practice to either increase number of branches or reduce plant height in red firespike. Branching was greatest using BA at all concentrations or DS at the highest concentrations. However, phytotoxicity caused by DS at high concentrations reduced marketability of plants. Higher concentrations of $\mathrm{BA}$ and DS decreased plant height, GI, inflorescence length and number, and increased the number of days to flowering. Low concentrations of BA (600 ppm) were most effective in promoting branching and producing uniform and marketable red firespike plants. 


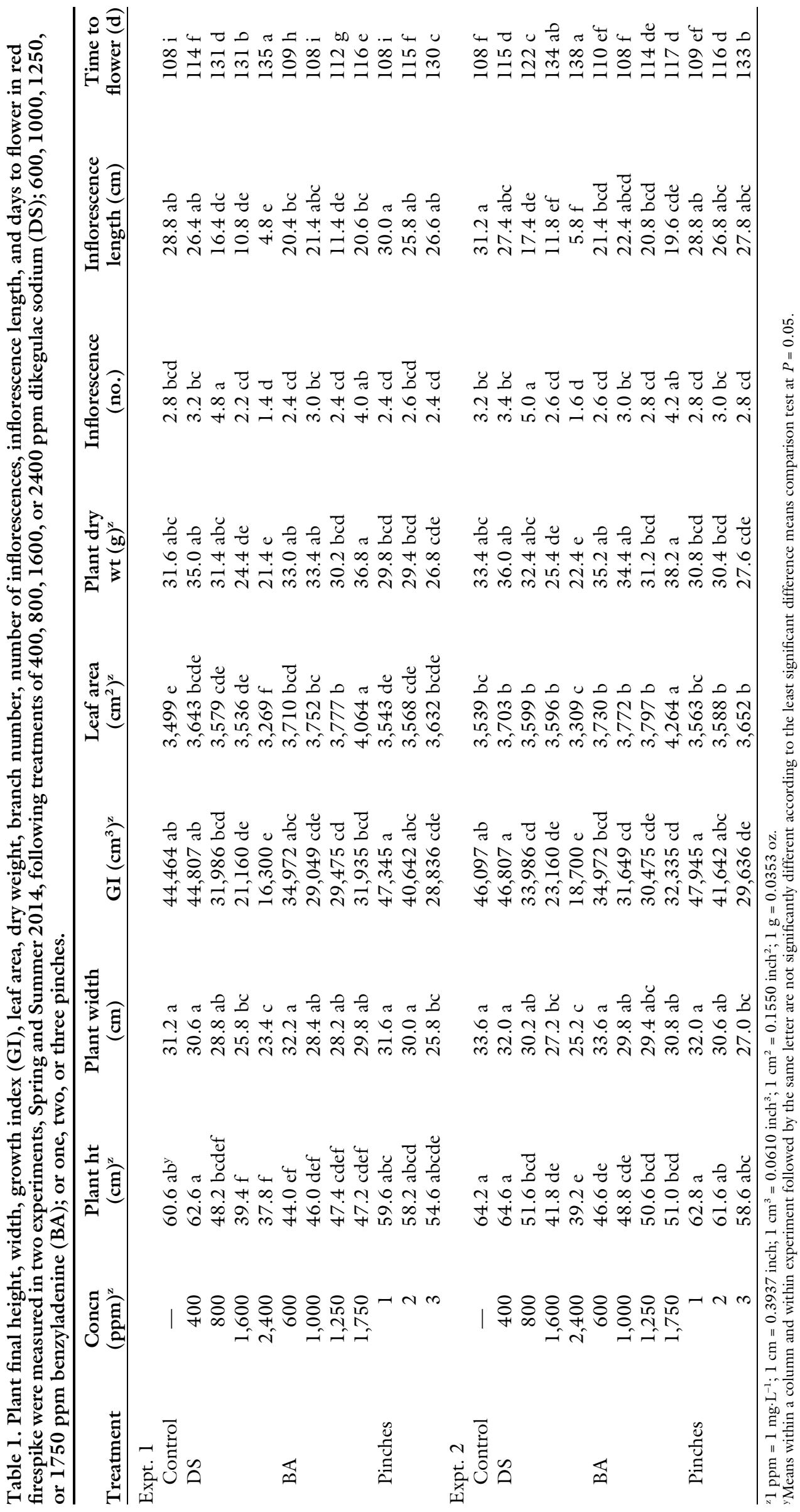




\section{Literature cited}

Arzee, T.H., H. Langenauer, and J. Gressel. 1977. Effects of dikegulac, a new growth regulator, on apical growth and development of three Compositae. Bot. Gaz. 138:18-28.

Beniwal, B.S., V.P. Ahlawat, and S. Rakesh. 2003. Studies on the effect of spacing and pinching on growth and flower production of chrysanthemum cv. Flirt. Haryana J. Hort. Sci. 32:228-229.

Carey, D., B. Whipker, I. McCall, and W. Buhler. 2008. Cytokinin based PGR affects growth of vegetative petunia. Proc. Plant Growth Regulat. Soc. Amer. 35: 85-89.

Cochran, D.R., A. Fulcher, and G. Bi. 2013. Efficacy of dikegulac sodium applied to pruned and unpruned 'Limelight' hydrangea grown at two locations in the southeastern United States. HortTechnology 23:836-842.

Currey, C.J. and J.E. Erwin. 2012. Foliar applications of plant growth regulators affect stem elongation and branching of 11 kalanchoe species. HortTechnology 22:338-344.

Daniel, T.F. and L.A. McDade. 1995. Additions to the Acanthaceae of Panama. Ann. Mo. Bot. Gard. 82:542-548.

Farris, M.E., G.J. Keever, J.R. Kessler, and J.W. Olive. 2009. Benzyladenine and cyclanilide promote shoot development and flowering of 'Moonbeam' Coreopsis. J. Environ. Hort. 27:176-182.

Grossman, M., J. Freeborn, H. Scoggins, and J. Latimer. 2012. Benzyladenine increases branching but reduces root growth of herbaceous perennial liners. HortScience 47:1085-1090.

Grossman, M., J. Freeborn, H. Scoggins, and J. Latimer. 2013. Timing of benzyladenine and dikegulac sodium application affects branching of liners and finished herbaceous perennial plants. HortScience 48:875-882.

Hester, K.A., G. Bi, M.A. Czarnota, A. Fulcher, G.J. Keever, J.H. Lieth, J.D. Orsi, B.E. Whipker, K. Sullivan, and C.L. Palmer. 2013. Impact of Augeo, Configure and Florel on hydrangea branching. J. Environ. Hort. 31:27-29.

Kawabata, O. and R.A. Criley. 1996. Dikegulac sodium spray enhances uniform regrowth of Murraya paniculata (L.) Jack Hedge. HortScience 31:244-246.

Keever, G.J. and T.J. Morrison. 2003. Multiple benzyladenine applications increase shoot formation in nandina. J. Environ. Hort. 21:144-147.

Larson, R.A. 1985. Growth regulators in floriculture. Hort. Rev. 7:454-461.

Latimer, J. and J. Freeborn. 2008. Enhance branching of Echinacea with PGRs. Greenhouse Prod. News. 18(4):24-28.
Latimer, J. and J. Freeborn. 2010. Branching enhancers, Configure (6-BA) and Augeo (dikegulac sodium), affect branching of herbaceous perennials. Proc. Plant Growth Regulat. Soc. Amer. 37:148152.

Meijón, M., R. Rodríquez, M.J. Cañal, and I. Feito. 2009. Improvement of compactness and floral quality in azalea by means of application of plant growth regulators. Sci. Hort. 119:169-175.

Norcini, J.G., J.H. Aldrich, and J.M. McDowell. 1994. Flowering response of Bongainvillea cultivars to dikegulac. HortScience 29:282-284.

Norcini, J.G., J.M. McDowell, and J.H. Aldrich. 1993. Dikegulac improves Bougainvillea flowering during two production seasons. HortScience 28: 119-121.

Rakesh, S., R.S. Singhrot, and B.S. Beniwal. 2003. Effect of $\mathrm{GA}_{3}$ and pinching on the growth and yield of chrysanthemum. Haryana J. Hort. Sci. 32:61-63.

Rezazadeh, A. and R.L. Harkess. 2015. Effects of pinching, number of cuttings per pot, and plant growth regulators on height control of purple firespike. HortTechnology 25:71-75.

Werner, T., V. Motyka, M. Strnad, and T. Schmülling. 2001. Regulation of plant growth by cytokinin. Proc. Natl. Acad. Sci. USA 98:10487-10492. 